\section{Acknowledgments.}

Financial support. This work was supported by the Research Fund of Emergency Project of Prevention and Control for COVID-19 of Hunan Province (grant nos. 2020SK3027 and 2020SK3028).

Conflicts of interest. All the authors declare no conflicts of interest related to this article.

\section{References}

1. Heymann D L, Shindo N. COVID-19: what is next for public health? Lancet 2020;395:542-545.

2. Ng O T, Marimuthu K, Chia P Y, et al. SARS-CoV-2 infection among travelers returning from Wuhan, China. N Engl J Med 2020;382:1476-1478.

3. WHO coronavirus disease dashboard. World Health Organization website. https://covid19.who.int/. Accessed November 15, 2020.

4. The latest situation of COVID-19 epidemic as of 24:00 on November 14. Chinese Center for Disease and Prevention website. http://www.chinacdc.cn/ jkzt/crb/zl/szkb_11803/jszl_11809/202011/t20201116_222730.html. Accessed November 15, 2020.

5. Wilder-Smith A, Freedman DO. Isolation, quarantine, social distancing and community containment: pivotal role for old-style public health measures in the novel coronavirus (2019-nCoV) outbreak. J Travel Med 2020;27(2):2.

6. Infectious disease prevention and control. Chinese Center for Disease and Prevention website. http://www.nhc.gov.cn/jkj/s2907/new_list.shtml?tdsou rcetag=s_pcqq_aiomsg. Accessed November 15, 2020.

7. Ong S, Tan YK, Chia PY, et al. Air, surface environmental, and personal protective equipment contamination by severe acute respiratory syndrome coronavirus 2 (SARS-CoV-2) from a symptomatic patient. JAMA 2020;323: 1610-1612.

8. Chu DK, Akl EA, Duda S, et al. Physical distancing, face masks, and eye protection to prevent person-to-person transmission of SARS-CoV-2 and COVID-19: a systematic review and meta-analysis. Lancet 2020;395:1973-1987.

9. Peto J. COVID-19 mass testing facilities could end the epidemic rapidly. BMJ 2020;368: m1163.

10. $\mathrm{LiCH}$, Tan CX, Wu AH, et al. COVID-19: the role of community in China's response. J R Soc Med 2020;113:280-281.

\title{
Coronavirus disease 2019 (COVID-19): Faith healing or science? An old-time problem
}

\author{
Marios Papadakis MD, PhD, MBA (1) \\ Department of Surgery II, University of Witten-Herdecke, Germany
}

To the Editor-Coronavirus disease 2019 (COVID-19) poses a major global challenge, with extreme and economic and social impacts affecting almost every aspect of life. Healthcare systems face unprecedented pressure, resulting in thousands of deaths daily. Intensive care units are the last line of defense against coronavirus. Fortunately, most intensive care unit (ICU) patients are discharged. However, positive outcomes are often attributed from patients and patients' family members to the supernatural power of God. Sadly, there is a strong tendency to blame healthcare professionals, especially critical care physicians, for negative outcomes.

Surprisingly, this attitude is as old as medicine itself. Common failure to appreciate science dates back to the Hippocrates' time. Hippocrates, the father of medicine, flourished in the fifth century BC. His teachings have been preserved in the Corpus Hippocraticum, a collection of $\sim 60$ medical works. Although their authorship is largely unknown, all works are believed to reflect the principles of hippocratic medicine. In one of the letters to his friend Democritus, Hippocrates states that it was common for good outcomes to be attributed to divine intervention and failures to be charged to caregivers:

"Most people do not praise the successes of medical science, and they often
attribute them to the gods. But if nature is recalcitrant and weakens the
patient, then they blame the physician and pass over the divine. I think that
medical science is allotted more reproach than honor. And, in fact, I myself
have not reached the goal of medicine, though I am now old. And indeed,

Author for correspondence: Dr. Marios Papadakis, E-mail: marios_papadakis@ yahoo.gr

Cite this article: Papadakis M. (2022). Coronavirus disease 2019 (COVID-19): Faith healing or science? An old-time problem. Infection Control \& Hospital Epidemiology, 43: 1098, https://doi.org/10.1017/ice.2021.198 neither did its founder, Asclepius, but he too, was inconsistent in many things, as books of those who recorded it have conveyed to us." ${ }^{\prime}$

Similarly, nowadays many people are willing to attribute to supernatural intervention any interference with nature, especially when divine involvement has been requested. The phenomenon has its origin in the fact that most physicians encounter or have encountered outcomes they cannot explain using natural criteria and terms such as spontaneous remissions of incurable malignancies. Although scientific miracles are not clearly defined, most physicians do believe that miracles occur today and that religion is a reliable and necessary guide to life. ${ }^{2}$ However, we should not forget that healthcare professionals risk their own health helping the humanity fight this invisible enemy. Therefore, gratitude is the best attitude.

\section{Acknowledgments.}

Financial support. No financial support was provided relevant to this article.

Conflicts of interest. All authors report no conflicts of interest relevant to this article.

\section{References}

1. Smith W. Hippocrates: Pseudepigraphic Writings. Leiden: Brill, 1990.

2. Orr R. Responding to patient beliefs in miracles. South Med J 2007; 100:1263-1267. 